\title{
Moldova: Small country - big problem! Corruption and a mono-garchy
}

\author{
Petrus C. Van Duyne and Brendan Quirke ${ }^{1}$
}

\section{Introduction}

What is corruption? One of the many answers to this question is: "It is a misuse of public office for private gain" (Svensson, 2005: 19). Though this short definition is widely used, it is imprecise. It intends to cover a too wide range of law breaking, from bribery to embezzlement to fraud, clientelism and secret dealings. We prefer to bring all these modes of conduct under the umbrella of breach of integrity. However, the concept of integrity needs further precision. The online Oxford Dictionary brings us one step further with the following definition of integrity: "The quality of being honest and having strong moral principles." That leaves us to define the constituting elements of honesty and moral principles. We suggest that these concern truthfulness and behaving according to yardsticks. According to Van Duyne (2001), what is central in the concept is the decision making according to yardsticks: corruption erodes the integrity of decision making and leads to bending or evading its standards which an honest decision maker should refuse. Van Duyne (2001) formulates it as follows:

"Corruption is an improbity or decay in the decision-making process in which a decision-maker (in a private corporation or in a public service) consents or demands to deviate from the criterion, which should rule his decision making, in exchange for a reward, the promise or expectation of it".

We will use the concepts of corruption and integrity breaches interchangeably, but always within the framework of the integrity of decision making.

1 The authors are based, respectively, at Utrecht University, The Netherlands, and at Manchester University, UK. 
As we will see, it is the deep and pervasive erosion of the integrity of the decision making in the public administration and private sector, which affects the welfare of the peoples. In our study this awkward predicament concerns Moldova, which does not stand alone in this regard. In fact, the whole western Black Sea and Balkan region is characterised by a high level of corruption (Emerson et al., 2017; McDevit, 2015; Kononczuk et al., 2017). On the Corruption Perceptions Index 2017 of Transparency International, of which the scale ranges from 10 (highly corrupt) and 100 (very clean) and with a global average of 43, Moldova scores 31; Ukraine 30; Bosnia and Herzegovina 38; Albania 38; Macedonia 35; Serbia 41; Bulgaria 43; Montenegro 43 and Romania 48 (Transparency International, 2018). It is clear that Moldova together with Ukraine, is at the bottom of this apparently deeply corrupt region.

Corruption is a global concern and Moldova underwrites this: it is (or will become) a signatory of a number of international conventions against corruption. ${ }^{2}$ However, this legal compliance did not make the country less corrupt though we still lack a systematic knowledge of the backgrounds and facets of corruption in Moldova. This chapter aims to make a reconnaissance by bringing together what is known about corruption in this country. The sources for this study are not rich: corruption in Moldova seems to be under-researched. The consulted sources consist mainly of open English language sources, mainly from Moldovan institutions and local authors whose publications were uploaded on various websites.

We will first look at the common denominator underlying the corruption in this region: the Soviet heritage.

2 The United Nations Convention against Corruption of the United Nations, in force since 14 December 2005; the Inter-American Convention against Corruption of the Organization of American States, in force since 6 March 1997; the Civil Law Convention on Corruption of the Council of Europe, adopted 4 November 1999; the Criminal Law Convention on Corruption of the Council of Europe, adopted 27 January 1999; the EU Convention against Corruption involving officials of the European Union, adopted on 25 June 1997; the African Union Convention on Preventing and Combating Corruption, adopted in 2003; the OECD Anti-Bribery Convention. 


\section{The Soviet corruption heritage}

Moldova is a small, relatively underdeveloped country sandwiched between Romania and Ukraine. The principality of Moldova was founded in the 1350s. It was controlled by the Ottoman Empire for almost 500 years until 1812, when the north-eastern part of the principality - Bessarabia was annexed by the Russian Empire. In 1918, Bessarabia became part of Romania but in 1940 was annexed again by the Soviet Union.

Whether in Tsarist or Soviet times, corruption has been endemic. As Markovska (2007) comments, in Pre- and Post-Revolutionary Russia, officials were often expected to 'live off the job' by extracting every penny they could from those who depended on their services (Markovska, 2007: 227). For Moldova it can be interpreted as a continuation of the Turkish style of governing the outlying provinces: officials (often Greek aristocrats) had to rent their position and reclaimed the expenses by living off their districts (the Phanariote era; Kurat and Bromley, 1976). Civil service positions became a commodity that could be sold or inherited (Chalidze (1977) quoted by Markovska and Isaeva (2007: 228). This was continued under the Bolshevik rule.

Jowitt (1983) observed that in the Soviet Union bribes "are being offered and taken for everything, ranging from certificates of place of residence, to apartments, to ministerial posts in the republics" which in his opinion were practices that sustained the privileged political cadre. Jowitt (1983) comments that the purchase and sale of positions for large sums of money signifies the profound institutionalisation of a structure of bribery and graft, from the bottom to the top of the pyramid of power.

Stefes (2003) quotes Konstantin Simis, a Jewish lawyer who was forced to leave the Soviet Union, who aptly observed: "it can be stated without fear of exaggeration that the average Soviet citizen was accompanied by bribery from womb to tomb". It exerted control over the distribution of the most basic scarce resources and services, causing a frantic search (Stefes, 2003; Clark and Wildavsky, 1990: 217). There were no control mechanisms in the one party state. Corrupt conduct was expected from most leading cadre: declining participation was unofficially sanctioned (Simis, 1982: 218). Finally, the rules that structured corrupt activities were refined and commonly known (Vaksberg, 1991: 6). 
Stefes (2003) poses the question: how did the myriad of opportunities to take bribes turn into a system of corruption? He believes that this was enabled by a system of clientelism within the state-party apparatus. He believes clientelism was built initially around the career ambitions of Soviet officials who realised that without the patronage there were no career prospects as socialist orthodoxy prevented a meritocratic promotion system to develop. So promotion became based on patronage.

This system created a profitable leverage towards citizens in need of permits and licenses (Simis, 1977: 38). Given the civil servants' power to stall, the citizens were accomplices as well as extorted victims (Stefes, 2003; Simis, 1982: 230). All ex-Soviet states shared this system.

\section{Towards capturing the Moldova state}

Apparently the Moldovan people accepted this heritage of 'corrupt business as usual': paying bribes as an expected expense in getting served by underpaid officials who considered these as regular fringe benefits.

Apart from this heritage, 'liberated' Moldova was the only Soviet successor state, which did not welcome its birth: the majority of the population speaks Romanian and wanted to join Romania. This was not to the liking of the Russian speaking minority (9\%) living east of the Dniester. With Russian armed support the Russian minority revolted in March 1992 and declared its own state: Transnistria, recognised by no other state but Russia. Meanwhile the Romanian state, just having cast off the oppression of its socialist leader Ceaucescu, showed little enthusiasm to embrace "little sister' Modova (Całus, 2016: 16). "Where to belong to?" remained an unanswered question: should Moldova move to the west and the EU or towards Putin's Russia? In populist versions this easy to understand divide remained dominant in all rhetoric. This went at the expense of proper democratic policy building from a social and economic ideas and conceptions.

As a corollary Moldova had to start its life without popular identification, feelings of belonging to a shared tradition, history, or a national pride. Who loves Moldova? Its own citizens in the last place, a sentiment reinforced by the dislike of its corrupt elite (Całus, 2016; Ch. 1 and p. 34). This is a socio-political undertone explaining the fragile state building. 
Given this Soviet pre-history, corruption was not a new problem, as Markovska (2007) observed. New was Moldova's road to an authoritarian regime. Unlike in its neighbour state Ukraine (Konończuk et al., 2017), Moldova developed in the first decade of its existence a genuine multiparty system and at every election the voters removed the then ruling party or coalition from office. The pluralism was also reflected in the many-sided media. However, as indicated above, this pluralism had no internal content derived from social-economic ideas. Actually, the Moldovan people experienced all this pluralism not as a democracy but as chaos and inefficiency. In an opinion survey in 2001, 57\% of the interviewees expressed their preference for an old-fashioned one-party system, which was also considered to be less corrupt (Całus, 2016a: 24). Apparently the people had not learned much from history.

At the election of 2001, the people got what it wanted, but at the expense of more corruption and a captured state. The Party of Communists obtained a majority in Parliament of 71 out of 101 seats. Its leader, Vladimir Voronin, became the President. Though formally the President has little power, Voronin controlled his party fully and through that Parliament. Nominating his cabinet allowed him to rule as if constitutional restrictions on the presidency did not exist (Całus, 2016a). Not only did he pack the cabinet with loyal followers, he also succeeded in subordinating the system of justice to his will by appointing loyal judges and prosecutors (Prosecutor General Office and Supreme Court). Next he extended his party's influence to the public media. An important extension of power consisted of weakening the local administrative units which numbers were enlarged from 12 to 32 by splitting them up (2002). This shrinking of size made them financially more dependent on the central government that now could better influence local elections. After capturing the state apparatus, the real 'big grab' was done by Voronin's son Oleg using his father's influence and connections to extend his businesses. Apart from intimidations, he claimed that firms owed him money and used false court orders from a bribed judge to reclaim these fake 'debts' (Całus, 2016a: 24).

Voronin completed the constitutional two terms as president till 2009, after which elections were held. After a lot of bickering for the election of 
a President ${ }^{3}$, Parliament was dissolved and snap elections were held, in which the Communists were defeated by what has been called the Alliance for European Integration (AEI), consisting of four opposition parties. The two oligarch party leaders of the two biggest parties were Vlad Filat (Liberal Democrats) and Vlad Plahotniuc (Democratic Party Moldova). Did this herald a change from the grabbing and greed of Voronin and son?

\section{Perfecting state capture}

Other than the name of the new coalition suggests - working towards Europe and its standards - the leaders of the parties in power showed hardly genuine interest in working towards the EU unless their interests were not threatened (BTI, Country report Moldova, 2018: §14). In fact, there is no other real programme but to enjoy the benefits of a EU rapprochement, in particular the coveted visa free travelling and EU development funds. There is a lot of lip service to keep EU delegates and international partners happy.

The two leaders who mattered are Vladimir Plahotniuc and Vladimir Filat. Plahotniuc is chairman of the Democratic Party (PDM). He is considered to be the wealthiest businessman in the country, with his net worth estimated at hundreds of million to over a billion dollars. Filat was a former Prime Minister and the President of Moldova's center-right Liberal Democratic Party (PLDM). His critics accuse him of having profited from corrupt privatisation practices.

In October 2009, less than a month after the AEI was sworn in, it made Parliament to adopt a law on public functions and the statute of the civil servants. This allowed the government to appoint or dismiss staff of the judiciary, law enforcement and regulatory bodies. For example: chairpersons and vice-chairpersons, the Prosecutor General and deputies, judges of the Constitutional Court (CC), the Supreme Council of Magistracy (SCM), and director and deputies of National Bank, the National Anti-corruption

3 According to Wikileak cables Voronin offered Marian Lupu who had recently crossed-over from the Communist to the Democratic Party, \$ 10 million for power sharing: he would become Speaker and Lupu president. But Lupu declined. www.theguardian.com/world/2010/dec/02/wikileaks-cables-moldovavoronin-bribe Accessed 7-10-2018. 
Centre and Chairperson and members of the Central Election Commission. ${ }^{4}$ In a ruling of 29 December 2010, concerning the dismissal of the Chairperson of the Supreme Court the Constitutional Court mitigated this arrogation of power by differentiating between the institutions of high political and high public interest, such as the courts which should be protected against political interference. However, the government mostly flouted this mandatory ruling. In fact, the coalition followed the lines of its secret agreement of August 2008 on the division of the positions between the three member parties. The Liberal Democrats under Filat 'got' the Central Election Commission (Transparency International et al., 2017: 8). The Democratic Party of Moldova (DPM) of Plahotniuc 'got' a strong foothold in the justice system which proved later to be of a most strategic value: the General Prosecutor's Office, that he did not hesitate to use for his own purposes. In addition, he got a preponderant influence over the Supreme Court, the Supreme Council of Magistracy and indirectly the courts of justice. With a touch of wry irony, Plahotniuc also got the anti-corruption bodies in his grip.

These two oligarchs, Filat of the Liberals Democratic Party of Moldova (DLPM) and Plahotniuc of the Democratic Party of Moldova shared the centre of political power. They proved also to be serious rivals, which is a formula for political instability. However, during the first coalition years they kept up appearances of stability to the EU in view of the coveted Association Agreement with the EU and the liberalisation of the EU visa regime in 2014. Also, as their majority was slim, it was in their interest to avoid new elections, though tensions were mounting. Prime Minister Filat, expressed after a few years his misgivings about the appointment policy and warned on July 2011 against what he qualified as the mafiotisation of the Republic (TI et al., 2017: 6). He also admitted that his party got control of the Central Election Commission, a perfect position for election manipulation. These outpourings lowered his trust with the population of whom two third considers elections unfair (Transparency International and CMI, 2017).

Filat's influence declined after an attempt to reclaim control over the General Prosecutor's Office in 2013 and lost subsequently his position as

4 For a full list see Transparency International et al., 2017, p. 5 
Prime Minister. Meanwhile, Plahotniuc' influence was increasing by bribery and intimidation (Całus, 2016a). The final battle between the two oligarchs two years later is of interest because it revealed how subserviently the Prosecutor General Office, Mr Harunjen, and the courts operated.

The opportunity to settle accounts came when the One Billion Banking Theft came to the open and Filat was accused by the main suspect Ilan Shor of passive corruption. As Plahotniuc 'owns' the General Prosecution Office he made the deputy Prosecutor come into rapid action against his rival. On October 2015, Parliament was informed of the alleged Filat's wrongdoing and while violating its own procedural rules, hastily stripped him of his immunity, whereupon the Prosecutor General had him arrested immediately (TI, 2017). After a trial behind closed doors he was convicted to nine years prison. Now Plahotniuc was the only main oligarch left. $\mathrm{He}$ could be satisfied: he was now a 'mono-garch'. Having no other public position, he could dominate the 'ship of state' without any accountability.

\section{The functioning of the 'ship of state'}

The 'ship of state' is a metaphor for describing the government as standing on the command bridge; as the legislative determining the course; the mechanisms of the rule of law system to maintain order, and the executive to follow orders to keep the ship afloat. How is the Moldovan ship of state sailing?

\section{Parliament and political parties}

When there is systematic and grand corruption, there is most often a direct political link because at this level political decision making processes are affected. This does not only concern the direct benefits, but also the system of mutual protection: corrupt actors must have the clout to thwart anti-corruption measures and policies. That is often denoted with the abstract euphemism: "there is no political will to fight corruption". That is too freefloating: one must look at the perpetrators and all who abet their corrupt conduct. In our narrative this concerns corrupt politicians and their parties in the Moldovan Parliament of which the most important are: 
- The Liberal Democratic Party (PLDM)

- Party of Socialists of Republic of Moldova (PSRM)

- Party of Communists of Republic Moldova (PCRM)

- The Democratic Party of Moldova (DPM)

- The Liberal Party (LP)

We have noted earlier that in Moldovan politics the content of party programmes are irrelevant. Relevant are the leading persons, or as the chairman of the Constitutional Court observed: "Moldovan political parties are authoritarian entities, dominated by 'Leader's cult', without internal democracy and political visions". ${ }^{5}$ Hence we focus on politically leading actors: not a full picture gallery of 'who is who', but only those of whom enough is known in relation to systematic corruption.

In the previous sections we have already met Vladimir Voronin of the communist party PCRM who ruled two terms from 2001-2009. As mentioned, he is important because he set out to subordinate the administration of justice by skilfully appointing colourless and pliant figures on key positions (Całus, 2016). As we have seen, next came the regional administration, made financially dependent on the central government: non-communist districts got less money (Całus, 2016a: 24). His son Oleg benefitted from public contracts and preferences. With the support of corrupt judges he raided allegedly indebted corporations.

The scene changed in 2009, when this 'one-party grabbing' was replaced by a series of coalition governments of parties who were also not averse of sharing the grabbing spree.

Apart from that, the coalition worked uneasily together under their umbrella of the Alliance for European Integration. Nominally pro-Europe, their main energy was devoted to dividing the spoils including the 'rights' to nominate the top ranks of the law enforcement and supervisory institutions such as prosecutor general, chief of the fiscal service, governor of the National Bank of Moldova or the chief of the Central Electoral Commission (included in a confidential protocol August 2009). Tensions between the liberals under Filat and Democrats under Plahotniuc soured their relation. It came to a culmination with the arrest of the Filat (October, 2015)

5 https://www.europalibera.org/a/27209223.html. 
because of suspicions of passive corruption involvement and his hasty trial as described in the previous section (see p. 384).

With the main rival neutralised the power relation in Parliament had changed. Still, Plahotniuc' DPM was too small: it got only $12-16 \%$ of the votes at the elections. To get more seats the businessman came to the fore: Bribery was one of the convincing methods to lure MPs from another parties ('floor crossing'). A communist MP recalled: “An MP from DPM proposed me a very consistent remuneration and functions for relatives to leave the faction" (Transparency International et al., 2017: 14). The result was a 'floor crossing' to the DPM: 14 communist MPs, two liberal and one socialist MP and 17 of the liberal democrats changed sides to the DPM. ${ }^{6}$ With this outcome one can say that the mono-garch, Plahotniuc, succeeded in capturing the Moldovan legislature, while he has no official position in any of the branches of public administration or Parliament.

Floor crossing was the leverage to get controversial bills accepted. For example, against all advice and protests from western partners (US, EU) and international institutions (IMF, OECD), Parliament adopted in July 2018 the Fiscal Reform Package, together with Capital Amnesty implying that illegal or non-reported funds or assets can be legalised at a $3 \%$ payment of the declared value, while the normal income tax rate is $7-18 \%$. The withheld assets declarations can be submitted 1 December 2018 till 28 February 2019. In fact this is money laundering by law.

\section{The functioning of the juridical system}

It is difficult to determine to what extent the law enforcement system operates adequately and impartially: what are the yardsticks for a 'fair trial'? This is a matter of interpretation. In some cases, there is little room for interpretation. For example, the useless display of police power in the trial against Filat compared to the soft treatment of the main criminal operator, Ilan Shor. Therefore, we restrict our search to explicit critical mentions in the studies and reports on the administration of justice.

There are different aims for abusing the judicial system. In the first place, one can exert pressure to get a favourable verdict or ruling from the

6 Unsurprisingly, three attempts to introduce a bill against this practice of floor crossing were halted. 
court; in the second place, the law enforcement system can be used to intimidate opponents or, in the third place, to punish officials for 'wrong decisions': against the interest of the ruling party or to deter others. Examples will be given below.

One of the early critical mentions came from one of the main actors: Filat himself, criticising that the DPM (rather, Plahotniuc himself) has a decisive influence on appointments for the top functions: in the judiciary, General Prosecution Office and National Anti-Corruption Centre (Transparency International el al., 2017) and other supervisory and regulatory bodies. This is what Filat called the mafiotization of top appointments (see, TI, 2017: 5): staffing essential institutions with compliant personnel. However, this is a strong statement from someone being directly 'in the know' while regretting that his influence was on the wane. Are there more sources which may shed light on this delicate matter of lack of judicial integrity?

Though systematic research is lacking, the cases described in the literature and sometimes also the public upheaval caused by a suspicious verdict provide good illustrations of how the legal apparatus can be abused. Should that all be attributed to the DPM and behind that Vlad Plahotniuc? There is consensus about this among authors (Catus, 2016a; Gribincea, 2017; Hriptievski, 2017; Prohnitchi, 2018), however, consensus is no proof. Allegations that the Supreme Court of Justice is under influence of Plahotniuc through his power of appointment is of course refuted by the president of this Court, but questions remain. The same applies to the Prosecutor General, Harunjen, under whose management the Anti-Corruption Prosecution Service hardly functioned, who showed very little zeal in handling the One Billion Bank Theft, and who lives in a dwelling which cannot be paid from his salary. All this was no hindrance to an expeditious appointment on 8 December 2016, behind closed doors (Transparency International, 2017; Gribincea, 2017). In the next section we provide a selection of examples of (ab)using the system of justice.

\section{a. Favouritism, intimidation or punishment}

\section{Sorin Pleşca}

The case against Sorin Pleșca may illustrate the political influence on the outcome of a prosecution. In March 2016 Sorin Pleşca shot his brother "by accident". He ran away and stayed two weeks in hiding after which he was 
found. He was charged with "murder from imprudence" ("death by criminal negligence"), but after two and a half month the case was closed as "the parties reached an agreement". How could the prosecutor reach such a decision in a man-slaughter case? At the end of the year Sorin got a job at the embassy of Moldova in Turkey and his father, Nae-Simion Pleşca, sitting in Parliament for the LDPM defected to the DPM of Plahotniuc. Together with five other turncoats he helped to install the new Filip government of the same DPM. (TI et al., 2017: 27).

\section{Valeriu Guma}

This MP for the DPM (Plahotniuc) was convicted in April 2013, in Romania for corrupting the General Director of the State Assets Recovery to four years imprisonment. However, Guma absconded to Moldova. Thereupon, the Court in Bucharest requested the Moldovan authorities to recognise the verdict and execute the punishment (transfer of execution of verdicts). But Guma as MP still enjoyed the privilege of immunity, which the Parliament did not want to withdraw. When his immunity expired, the Moldavian Court ignored the Romanian request and converted the punishment into a suspended imprisonment of four years.

\section{Mayor Filipov of the town Taraclia}

Mayor Filipov was accused of cutting 31 trees in the courtyard of the town hall, though this was the responsibility of specialised services in the municipality. He was nevertheless prosecuted for causing damage, but was in first instance acquitted. However, the Cahul Court of Appeal convicted him to a fine and compensation of the damage. More important, in addition, he was also deprived of the right to hold public office for two years, which effectively crippled him politically. The SCJ annulled this sentence and referred the case for retrial. The mayor stated that this was a revenge for his refusal to join the DPM in the local elections in 2015 (Gribincea, 2017) ${ }^{7}$

7 To many this did not appear a loose accusation. The Congress of Local Authorities from Moldova demanded reinstalling him as mayor. Even the EU ambassador and the US embassy expressed their concern, a very exceptionally step. 


\section{The case of Basarabeasca's mayor}

In March 2017 the mayor of Basarabeasca, Valentin Cumpoies, was arrested and put into preventive custody for 30 days. The charge was negligence in preventing a citizen to abuse his 13 year old daughter to provide sexual services. Whether this misconduct or the mayor's liability was proven is not known: the case is pending, but the damage to the mayor is done. Cumpoies is member of Our Party, an extra-parliamentary party highly critical of Plahotniuc and his DPM. The Congress of Local Authorities of Moldova protested strongly against this "unprecedented and unjustified arrest" (TI et al., 2017: 30).

\section{The three stealing ministers}

In the Moldovan media these examples were discussed as examples of 'selective justice' with three ministers who were accused of abuse of office: illegally selling state property in February 2013. One minister was of the democratic party (Plahotniuc), the others liberal democrats. The latter accused saw their case quickly sent to court. The democrat minister's case was halted, despite documented accusations by the accountant (May 2013). This got public, but still no prosecution followed (Gribincea, 2017: 5).

\section{The case of judge Manole}

The case of Domnica Manole, judge at the Chisinau Court of Appeals, is illustrative for the whole judicial system in Moldova. The case concerns an attempt of a group of citizens to organise a referendum on the constitution. This is only possible with 200.000 signatures including 20.000 from at least half the administrative units as counted in 2000. The referendum group met these conditions, but Central Election Commission (CEC) refused to organise a referendum. In appeal the Court annulled the ruling of the CEC, which went in appeal against at the Supreme Court of Justice (SCJ). April 2016, the appeal verdict was annulled and the decision of the CEC upheld. The reason was that after the referendum law of 2000, under the communist leadership of Voronin a new regional division of the country was determined in 2002 with many more but smaller units. This implied that meeting the referendum conditions became impossible: some units did not even have enough voters. However, the referendum law was never adapted to this new regional division. So, judge Manole interpreted the law such that this referendum can work with the old regional division of 2000, 
while the SCJ ruled that only the 2002 division was valid. That was not the end of the matter. The SCJ took seriously offence at judge Manole daring to interpret the law: that is the privilege of the Constitutional Court. Subsequently, on $23^{\text {rd }}$ May 2016, the CEC submitted a criminal complaint of abuse of office against the judge to the General Prosecution Office. The next day, with unusual speed, the Interim Prosecutor requested the Superior Council of Magistrates permission to initiate criminal procedures. In a closed session the Council gave permission, against which Manole appealed at the SCJ, but now the procedure began to stall: after a year the case still has not been reviewed and judge Manole remains suspended.

The case of Manole was considered important for the independence of the judiciary and caused much upheaval. Judges from the Chisinau Court of appeal expressed their support for the judge and also the EU and the US embassies expressed again their concern.

The struggle of judge Manola with the hierarchy of the justice system is important for three reasons. In the first place, the referendum on the constitution was the last thing the ruling elite wanted: it was prepared to do anything to forestall it. In the second place, though the danger of a referendum was in the end averted by the SCJ, the DPM - through their proxies in the CEC and General Prosecutor - may have aimed to make their point: "don't dare to interpret the constitution by yourself or else we initiate a criminal investigation", even if interpreting laws is the main metier of judges. In the third place, by making this point the ruling elite clearly set a limit to the judicial independence, as was also observed by one of the protesting SCJ judges: to "initiate criminal investigation in this case sets a dangerous precedent for the independence of judiciary".

Transparency International et al., (2018) is more direct in their conclusion: there are strong reasons to doubt the independence of the judiciary. The appointment power of the DPM regarding the top echelons of the judiciary, stemming from the informal interparty agreement 2009/2010, and a personnel policy (see below) enables a powerful influence on the work of the courts. We will therefore discuss these personnel management tools next. 


\section{b. Appointment and promotion}

Appointment and promotion can be considered very effective bribes: it is a once in a lifetime corruption, after which one remains entangled in a patron-client relationship. And it is cheap: no money changes hands.

Concerning the important function of the President of the Supreme Court of Justice, there is no documented evidence supporting Filat's claim that the Liberal Party had the 'right' to nominate the President or other staff. With the demise of Filat, Plahotniuc would have taken over. Naturally the President, Poalelungi, denies emphatically that he would be a 'Plahotniuc man'. Nevertheless, there are no examples of SCJ decisions which were opposed to the interests of DPM or the business network of Plahotniuc. See Manola's fate above, who issued a verdict that could harm the elite's interests.

The legal procedure of appointment and promotion looks solidly based on merits. The selection of candidate judges or the promotion of judges proceeds in a two-step way (Transparency International et al., 2017; Hriptievschi, 2017). There are: (1) the graduation examination at the National Institute of Justice (for candidate judges) or performance evaluation (for judges) and (2) the evaluation by the Career and Selection Board. This Career Board inspects the points in the selection and promotion reports and gives a reasoned judgment. This is subsequently presented to the Superior Council of Magistracy (SCM), the supervisory body partly politically appointed. The SCM must propose the candidates or judges with the highest marks to the President of Moldova for an appointment or promotion. What do we know about this procedure based on merits only?

It appears that the SCM hardly takes notice of the marking by the Career Board. Transparency International et al. (2017: 17) Hriptievschi (2017) and (Gribinscea, 2017) observed that candidates or judges with lower points are systematically preferred to candidates with higher points: the authors mention eleven cases (six for the Courts of Appeal and five for the Supreme Court) while no reasons were given for ignoring the rating of the Career Board.

There are also many cases with 'integrity issues', in which proposed candidates or judges' promotions were refused by the President: about 80 in the period 2002-2015. The President's reasons were: discrediting justice; lack of objectivity; possession of unjustified wealth or other 'integrity 
issues'. The SCM has a considerable power to ignore the refusal of the President, because he can refuse only once: by again proposing the rejected candidate with a two-third majority the SCM proposal must be accepted, whether reasons are given or not (mostly). So, despite the serious reasons of the President for not accepting candidates or promotions, the SCM maintained 55 questionable proposals: again no reasons provided (Transparency International, et al., 2017: 18).

The way the top position of deputy President of the Supreme Court was filled, is telling. First, on April 2015, a vacancy was created by accusing the then deputy President of manipulating a new Integrated Case Management System. She felt pressured to resign which may have been the intention: nothing was heard of this serious allegation, while the vacancy remained open. The candidate judge for this position, an outspoken personality, was passed, again no reasons given. At the end (December 2016) an inconspicuous judge with a history of controversial decisions was proposed instead (Hriptievschi, 2017).

It is also striking that not having declared one's income and assets fully, remained unheeded, also with appointments at the SCJ which should be a role model. One judge was low in the ranking, had little experience and failed asset declaration: she stated that her Porsch was bought for only $€$ 500. Still, she was hastily proposed for appointment - even before the investigation of her asset declaration. In a Public Appeal on 8 February 2016, Civil Society Organisations expressed their concern about the nomination policy of the SCM, repeatedly ignoring the Presidents references at 'integrity issues' of candidates. ${ }^{8}$

There are also indications that in 2012, the SCM was warned by the Security and Intelligence Service of the involvement of judges in the Russian Laundromat. However, the SCM did not interfere till 2016. Then a number of judges involved got a positive evaluation and were promoted to administrative positions or the Court of Appeal (TI et al., 2017: 32).

It is almost a euphemism to say that the functioning of the Superior Council of Magistracy in matters of appointment and promotion is worrying. It is selective and non-transparent, giving the impression of punishing judges with a frank mind and furthering judges with an integrity risk. By

8 http://crjm.org/wp-content/uploads/2016/02/2016-02-08-Apel-CarieraJudecatori-ENG.pdf 
not giving reasons for its decisions the SCM shirks public accountability (Hriptievschi (2017).

\section{c. Tools against integrity breaches in the judiciary}

Within the structure of the justice system there are tools to prevent or sanction breaches of integrity principles. How do these function? TI et al. (2017: 20) and Hriptievschi (2017) inspected a number of cases to determine how the internal correction system responded to signs of breaches of integrity. As far as the signs came from civil society, for example from investigative journalists, the correction system is hardly functioning, reinforcing the lack of trust of $89,6 \%$ expressed by respondents in the Public Opinion Barometer. ${ }^{9}$

As we have already observed in the sections above, the asset declaration by judges is repeatedly ignored. If that is brought to the attention of the superiors, no action follows with one exception: one judge was fined with $€ 750$ for defects in her asset declaration.

A tool to prevent corruption is to randomise the distribution of cases over the judges in the courts. However, this system is also vulnerable to manipulation or suitable to accuse someone of having done so. We mentioned the example of the deputy President of the SCJ who was in 2015 accused of such a manipulation, allegedly just to get rid of the judge, an often observed ploy to harass someone out of the organisation.

The procedure for establishing disciplinary responsibility is a complicated tool: it exists of five levels. On each level a disciplinary case can be halted, while serious doubts about the integrity of the judge remain. The first level is the Judicial Inspection, which examines the complaint which it can reject. There were suspicions that the Judicial Inspection do not investigate sufficiently, particularly in cases in which chairpersons or judges from higher courts were involved (Hriptievschi, 2017). In one case the Judge-Inspector was himself in conflict of interest. ${ }^{10}$ Evidence can also be ignored, such as the audio-recording of the President of the Rîșcani Court, shouting and fulminating against a defence attorney and threatening his

9 Institute for Public Policies, Public Opinion Barometer, October 2016: http://www.bop.ipp.md/result?type=bar.

10 The President of the Court he investigated was the judge who examined a case in which the Inspector's wife was involved (Transparency International, et al., 2017:21). 
client. The Disciplinary Board stopped the procedure for lack of evidence. In various cases in which judges from the SCJ were involved the SCM annulled the disciplinary sanctions (Transparency International et al., 2017: 21-22).

To conclude, there are serious indications that the disciplinary procedures are used selectively and ineffectively. They cannot be considered to have a preventive or 'self-cleaning' function to further integrity.

Altogether there are ample indications that the system of justice is illequipped to keep its own part of the 'ship of state' clean. There are severe doubts of its independence: it is often selective and non-transparent. How that looks like is illustrated by the ill-famous Billion Bank Theft.

\section{d. The Billion Bank Theft}

The great Moldovan Bank Robbery sounds like the title of a caper movie - it isn't! Over a period of two years, approximately 1 billion dollars were embezzled from three Moldovan banks causing them to collapse in November 2014. The banks concerned were: Unibank (UB); Banka Sociala (BS) and Banca de Economii Moldova (BEM). According to a report in February 2017 by the London based auditing firm, Kroll, the three banks were subject to a large co-ordinated fraud from 2012 to 2014 . The fraud was committed by issuing of hundreds of loans to linked companies. The majority of the loans with no or fake collateral were processed or laundered through two Latvian banks. Part of the loan funds were then channelled back to Moldova to repay existing loans and to allow the continuation of more dubious lending. At least $\$ 600$ million was distributed to other destinations: shell firms in the UK and offshore corporations (Kroll, 2017).

A large number of Moldovan companies were judged to be working together on this fraud. The companies were linked to a Mr Ilan Shor, high manager of the BEM and of the Shor Group. According to Kroll (2017), at least 77 companies with accounts at the three Moldovan banks concerned made up this group of companies. Individuals and companies linked to the Shor group increased their ownership interest by buying shares in the three Moldovan banks allowing them control of management. Companies linked to the Shor group also provided the required corporate and bank structures enabling this fraud.

\section{The aftermath: trials, convictions and asset recovery}


Though this heist was enormous and well organised, what is important in our narrative is the way it was handled. In the first place, according to the Centre for Combating Economic Crime and Corruption (no date), the response of the government was slow, secretive and selective, mainly targeting political rivals in the ruling coalition: most important the earlier mentioned Vlad Filat. ${ }^{11}$ In the second place, there was also not much transparency in the handling of this case: the extent of the fraud came only piecemeal to the open. The Kroll investigative report was not intended for publication but was leaked anyhow. The investigative team of journalists, working in an association Zeppelin Investigations (2018), judged the report shallow and incomplete. The follow-up report is not yet available. The secret attempt to bail out three affected banks was revealed nevertheless and led to steep inflation, the fall of the government and broad public protests.

Naturally, the protest of the public was directed against the political and economic elite suspected of having a stake in the scam, in the first place the oligarch Plachotniuc. However, there was no evidence of his direct involvement: no "smoking gun". It remained unclear who benefitted of this robbery: the number of beneficiaries should be far larger than the handful prosecuted defendants. Fourteen acting or former judges and three bailiffs have been arrested for their alleged involvement Reuters (2017) mentions that 40 people have either benefitted from the scam or facilitated it.

The three defendants getting the main law enforcement and media attention were: Vlad Filat, the ex-Prime Minister and now opponent to Plahotniuc; the young rich businessman and politician, Ilat Shor, the previous chairman of Banca di Economii and mayor of the small town Orhei in the centre of Moldova. The third defendant was Veaceslav Platon, businessman and parliamentarian.

As mentioned, Shor was leading the so-called Shor Group and was the main operator of the scheme. He was arrested and placed under house arrest in May 2015 but nevertheless allowed to run for mayor of the small town Orhei, which he surprisingly won with $62 \%$ of the votes. In June 2016, he was arrested again and charged, but after two months custody released after denouncing all accomplices involved, in particular disclosing the bribes ( $\$ 250$ million and expensive cars) he gave to ex-Prime Minister Filat. However, for this active bribery he was not prosecuted. That

11 http://www.cccec.md/the-moldovan-banking-scandal/ 
omission did not save him: in June 2017, he was convicted for fraud and money laundering and sentenced to seven years and six months imprisonment. He called it all a conspiracy of the government and NGOs against him. He appealed against this sentence and pending this appeal was released to return to the mayor's office (Transparency International et al., 2017).

His investigation and trial took more than two years with the appeal procedure still on-going. At the time of writing he succeeded in drawing out the trial procedures (or was allowed to).

Filat got a rougher and also much quicker treatment: six months till the verdict in first instance, and eight month for the appeal procedure (Transparency International et al., 2017: 12). As mentioned in the previous section, after being accused by Shor to have received money and cars, the Prosecutor General had him arrested in Parliament with a lot of police showing. In Juni 2016, Filat was sentenced for passive corruption and convicted to nine years imprisonment. In addition, he was banned from holding public offices for the term of five years. The trial was behind closed doors and the verdict was not publicised. Only PublikaTV of Vlad Plahotniuc was allowed to be present. Throughout the trial he was surrounded by an excessive number of Special Forces officers. ${ }^{12}$ Filat appealed to the Supreme Court of Justice and the European Court for Human Rights of which the procedure is still pending.

This was still mild compared to the sentence meted out to the third perpetrator in this scheme: Veaceslav Platon, with Shor also heavily involved in the $\$ 20$ billion Russian laundromat which ran through Moldovan banks (Zeppelin investigations, 2018). He was charged with stealing \$40 million from the Banca de Economii. Platon was barred from his trial because of 'bad behaviour'. Also to the public, the trial proceeded behind closed doors. Only the verdict was read in public (April 2017), with the defendant present. He used to occasion to shout to his judges: "Judges, look into my eye! Aren't you ashamed? This is not a sentence, this is a politically rigged inquisition orchestrated by your master, Vlad Plahotniuc, who should be

$12 \mathrm{https}$ //en.crimemoldova.com/news/social/vlad-filat-sues-moldova-to-the-european-court-of-human-rights-for-violating-his-rights-in-the-trial/ http://www.intellinews.com/former-pm-filat-sues-moldova-through-european-court-of-human-rights-127058/ 
put in prison himself! This is not a trial, this is Plahotniuc's menagerie." Platon was convicted to 18 years imprisonment. ${ }^{13}$

The aftermath of the mega fraud in terms of asset recovery remains unmentioned as nothing has been recovered thus far. The same applies to the beneficiaries of these huge sums of money. There are persistent indications that the National Bank, some MPs and the Supreme Council of Magistracy were informed at an early stage of the scam. Also the Prosecutor General showed no sense of urgency to come into action (Gribincea, 2018). Despite lofty intentions about funds recovery, there is no orderly asset recovery report available. Also the EU foreign affairs Commissioner Morgherini called in May 2018 for more recovery action, but in vain.

To summarise: the prosecution and trials displayed a high degree of selectivity, bias in terms of treatment and severity of sentence and lack of transparency. The main criminal operator, Shor, was allowed to draw out all procedures, remaining at large as mayor of Orhei, while the other defendants were immediately put in custody. There was no legal transparency: the trials were behind closed doors and verdicts were not publicised.

\section{The executive and corruption}

Extending the metaphor of the ship of state to the executive of Moldova, would depict a boat's 'bridge' with the Prime Minister 'at the helm' supported by his responsible ministers and deputy ministers with the President as a ceremonial captain. However, this picture is far removed from the present state of affairs. Since 2009 there have been six governments. The changes were not a consequence of a battle of ideas derived from party programmes but of a of the disagreement of the division of the spoils between the democrats (DPM-Plahotniuc), the Liberal Democratic Party (LDPM-Filat) and the Liberal under Ghimpiu. This bickering went on and off, thinly concealed from the wester sponsors of the poor country. The big 1-Billion bank robbery caused additional instability and street protests. The government resigned.

13 https://en.interfax.com.ua/news/general/416902.html

Apart from these leading suspects, two other accomplices were mentioned as convicted for this scam to four and five year imprisonment. 
The new government (Democrats and Liberals), was headed by the weak and pliant Plahotniuc-man: Paval Filip. He was installed in January 2016 during an undisclosed, late-night ceremony which was only later confirmed by a press release from the president's office (Transparency International et al., 2017: 36). ${ }^{14}$

This was a grubby beginning but it reflected the real Plahotniuc' success: as the NGO Freedomhouse and Transparency International (2017) observed, the premier and the speaker of parliament were now also in his hands, "an unusual concentration of power" of a party whose ranking at the 2014 election was only fourth. As mentioned, the DPM was further strengthened by 22 MPs 'crossing floor' from the Liberals and Communists. ${ }^{15}$ In May 2017 the coalition broke up and the PLDM was replaced by the socialists (PSRM). Again, the majority of the ministers were appointed by the DPM, that is: Plahotniuc.

It bodes ill for the anti-corruption reforms in particular when it concerns the implementation of the reform laws that have been enacted since 2009.

In the first place, there is the reform of the Prosecution Office, August 2016. First there is the questionable appointment of the Prosecutor General Office: Mr. Harunjen having an income and property mismatch and otherwise a low performance in his previous job in the Anti-corruption Prosecution Service. To this comes the appointment of the deputy chief anticorruption prosecutor with also a low skills score and a comparable asset declaration problem (Gribincea, 2017: 4). These officials manage the Anticorruption Prosecution Office (APO) consisting of 50 prosecutors' positions: nine filled thus far. While it is the intention that they will handle high-level corruption cases, $75 \%$ of the cases are still petty corruption cases (Gribincea, 2017; Prohnitchi, 2018; Stefan et al., 2018). Meanwhile APO's budget lacks special funds to be used for special investigation activities. APO is further burdened by a too broad mandate under which it must also deal with cases that have nothing to do with corruption, such as fraud in the private sector or terrorist finances (Stefan et al., 2018: 14. APO's statistics look good, but its workload does not reflect a real prioritisation corrupt state capture.

14 https://freedomhouse.org/report/nations-transit/2017/moldova

15 By joining the Alliance for European Integration the communist defectors showed no qualms to forsake their pledge to the voters to steer Moldova towards Putin's Eurasia. 
Thus far, the attention for high-level corruption cases looks very biased: prosecution and conviction of members of the ruling parties and their associates are hard to find (one example, deputy minister of Economy, Triboi, March 2017 (TI et al., 2017, ). This reinforces the impression that the anti-corruption system is mainly used against opponents.

\section{The "guardian institutions"}

The Moldovan legal system is not without 'guardian institutions' whose functions are enshrined in law. But the question is not whether there are sufficient regulations, but how they are implemented. The following sections provide an outline of their functioning. For a proper evaluation more data are not available.

\section{a. The National Anti-Corruption Centre}

The NAC resulted from a reorganisation of the Center for Combating Economic Crimes and Corruption in 2012 and became an independent central public organisation, directly under the responsibility of the parliament. It is tasked to prevent, investigate and combat corruption and related offences. It has a personnel of 350 officers: among them 40 staff for prevention and ten analysts.

The political responsibility for the NAC is the (DPM dominated) parliament. According to Gribincea (2017) this is reflected in the investigation pattern: no corrupt DPM members or officials have been arrested with the exception of the Minister of Economy, Valeriu Triboi and Minister of Agriculture, Eduard Grama. ${ }^{16}$

16 Triboi bought a building for a low price from a state enterprise and had it renovated by other state enterprises. That was known for years. But now another development may have plaid a role in bringing this to the open: a gas deal with Ukraine or Transnistria. The minister favoured the Ukraine agreement, but was arrested just before concluding it, preventing the deal. A few months later the gas agreement was made with Transnistria after all (TI, et al., 2017; p. 27-28). Grama was arrested in relation to a contested land deal, and was detained for 72 hours. http://www.moldova.org/en/minister-agriculture-eduard-grama-arrested-72-hours-corruption-charges/ 
NAC issued a Progress Report 2014-2015, which has also a chapter with a series of quantitative findings. Unfortunately the statistics are rather crude and elementary and must be used cautiously. Obviously they concern only concern detected cases. One can assume here a high 'dark number': most types of corruptions are consensual. Moreover, who will report a satisfactory criminal transaction to the authorities that are generally distrusted anyhow.

In the two reporting years the NAC detected 1.031 cases of corruption or corruption related crimes of which $66 \%$ were rated as "severe and extremely severe"; $24 \%$ as "less severe" and $10 \%$ as "minor". However, these qualifications are not operationalised, neither in terms of damage or in terms of affected morality.

Unfortunately the report does not provide a breakdown of these three severity categories over other variables, such as the suspected persons or the type of public services in which detected cases of corruption happened.

The data of the report indicate that more than $50 \%$ of the input consists of cases against police officers, doctors and 'individuals'. The text of the NAC report does not allow further differentiation, devaluating this statistical effort.

On a few subjects the NAC report provides us some interesting glimpses on sanctioning, also in relation of the size of the bribes. Of the 585 cases reviewed by the courts the judges pronounced in $83 \%$ a guilty verdict. If a prison sentence was imposed this was in $31 \%$ suspended.

The amount of money involved in the bribery seems modest: on average $€ 1.161$ in 2014 and $€ 2.751$ in 2015 . However, without a frequency distribution, a breakdown by other variables and the values of the medians, these figures rather raise the question why such an analysis has not been carried out. The same applies to the strange finding of the NAC that there is an inverse relationship between the value of the bribe and the fine imposed. With a bribe sum of less than $€ 2.500$ the relation between bribe and fine is 1:4; with a bribe between $€ 2.500$ and $€ 5.000$ the relation is $1: 1$; but with a bribe exceeding $€ 5.000$ the relationship changed to $4: 1$. The higher the bribe, the lower the fine. This finding goes at the heart of the principle of equality of justice. 


\section{b. The Anticorruption Prosecution Office}

The prosecution of corruption offences is naturally in the hands of the Prosecution Office, which was reinforced by the new Law on Prosecution Service of 2016, a (slow) follow-up of the 2011 Justice Sector Reform Strategy. The law strengthened the independence of the prosecutors. To lower the 'temptation' the salary of was doubled. An anticorruption Prosecution Office was established, intended for cases of high-level corruption cases.

Unfortunately this is an illustration of a successful reform on paper but failing in the implementation. The earlier mentioned appointment of the Prosecutor General Harunjen (see pp. 384, 387 and 399) head of the previous Anti-corruption Prosecution Centre raised suspicions. Summarised: little zeal; undeclared wealth and after a hasty procedure he was sworn in behind closed doors (Gribincea, 2017: 3). The selection of the deputy, also with a wealth-declaration issue and moderate ranking (a third place) cannot be considered as inspiring. It may be too early for a judgement, but Gribincea's (2017) observation that $75 \%$ of the workload of these specialised prosecutors still consists of small case strengthens the impression of another half-baked reform.

\section{c. The National Integrity Authority}

While the NAC is a law enforcement criminal law institution, the new broad integrity organisation will be the National Integrity Authority. This body, established by law in 2016, should result from the reorganisation of the National Integrity Commission to be accomplished by the Integrity Council. However, this did not appear to work. For unexplained reasons various deadlines for carrying out tasks were extended. It also proved difficult to fill the position of (deputy) president leading to substantial delays. In its annual survey of the governance of Moldova 2018, Freedom House concludes to a failure for 2017 and a "lack of political will" (which is rather a Plahotniuc issue) to see through the NIA reform and fight corruption.

According to Transparency International (2018: 2):

"more than one year after the adoption of the laws from the Integrity Package, their implementation did not go further than organizing the competition to fill the positions of Chair and Vice-Chair of the NIA, the 
procedures not yet being finalized. Obviously, delaying the reorganization of this institution jeopardizes the process of control of wealth and personal interests."

Perhaps the latter point is this issue at stake: processing the almost 65.000 declarations of assets and interests. Asset declaration can be an important tool for furthering integrity - if heeded at all. However, the landscape has changed and not in favour of this integrity tool. In an earlier section (p. xx) we pointed at the Capital Amnesty Law (August 2018) allowing a post hoc declaration of hidden (criminal) assets which will then be taxed by only $3 \%$ of its declared value. Though not mentioned explicitly, this seems at odds with the assets and interests declaration. Why report assets when all the fruits of corruption and other profitable crimes can be legalised by filling a form? The opposition and (western) foreign partners have expressed their concern that this act may turn Moldova into a laundering hub for the region and beyond. Given the experience with the Russian Laundromat no an exaggerated worry.

Meanwhile the National Integrity Authority is struggling to get born by an apparently disinterested political midwife. Against the background of this Capital Amnesty Law, the question arises whether the National Strategy of Integrity and Anticorruption (SNIA) for 2017-2020 (and within it the NIA) should be taken seriously in the first place (Prohnitchi, 2018).

\section{d. Independent media: shedding and shunning light}

The relation between corruption and the media is not a direct one. In our formal definition the concept of 'media' has no place unless the chief editor of a newspaper or TV station is bribed in their capacity of decision makers. However, that is a too formal approach. One of the functions of the media is shedding light on political or societal importance. The opposite, shunning light, is the built-in consequence of integrity breaches. Hence, for the corrupt elite capturing the media is an important requirement to keep the light out. It is therefore no accident that we so often find the mention of 'behind closed doors', behind which there is no room for a free press. Apart from closing doors there are smarter ways to neutralise the free media. How does that look like in this mono-garchy?

The simplest and legal approach is to establish a news firm oneself; then to take over an ailing company; or to increase influence on supervisory 
bodies and to get a grip on the revenue side of the media: the advertisement market. If that does not work sufficiently, old-fashioned Soviet means can be used: physical and psychological intimidation of journalists, such as assaulting, having journalists a few days detained by a willing police unit, stalking, spying and death threats, also against relatives (Freedom House, 2017: 8; 2018: 8).

Freedom House observes in their 2017 and 2018 reports a continuation of a near monopoly of Plahotniuc' news corporations, whether printed, radio or through television. He owns or controls through his proxies (his favoured mode of operation) four out of five nation TV stations, cable television channels, and three radio stations and controls a number of newspapers. His share of the media market is estimated between $60-70 \%$. In addition he has a firm grip (about 70\%) on the advertisement market, enabling him to put pressure on displeasing new stations as well as the state media regulator. In individual cases he can also make cable operators cut disagreeable broadcasts: putting the 'television on black' (Całus, 2017: 4041). ${ }^{17}$ Of course, there is a law against media concentration, which is, however, circumvented by nominating straw men.

As a result, a 'light shunning' media system has developed to protect the interests of a small elite or to hide their deeds. The media actors themselves do not need to be directly bribed. A manipulation of advertising revenues, a captured police and judiciary and occasionally beating up a journalist, does not require bribing.

\section{Final state: the mono-garchy}

Given the available documentation about the legislative, the judiciary and the executive, as well as business conglomerate, Moldova differs clearly from the oligarchic power network of the neighbouring Ukraine

17 This happened on 20 January 2016, when Moldtelecom controlled by Plahotniuc blocked the signal of TV stations covering protests against the new government of Filip, Plahotniuc's nominee as Prime Minister. Another kind of interference occurred 27 August 2016: Moldova 1, cut covering independence day as soon as protesters showed up (Całus, 2017: 40). 
(Konończuk et al., 2017; Całus, 2016a). In this country a plurality of oligarchs persevered in maintaining a precarious balance of power, though the clan around Yanukovich lost its influence. In contrast, in Moldova the struggle for political dominance has (thus far) resulted in one surviving oligarch, Plahotniuc. So instead of an oligarchy one can speak of a monogarchy. This does not mean a return to a one party system which would formalise his power. Surveying the way Plahotniuc has operated since he reanimated the small Democratic Party after the Voronin era, one can observe that he uses to work via proxies. He is no office holder but a businessman who is just also acts as the chairman of the DPM. But otherwise he is rarely at the front line. While protecting his business interests by political means he remains unaccountable, but still in control.

What are the consequences of this state of the country? The positive side is that compared to the instability during the power sharing with cooligarch Filat, a certain stability has returned. However, this is a stability with stagnation, to protect business interests of one clan

\section{Conclusions}

Moldova a small country with a big problem: it had to make a difficult transition into the post-Soviet world. It has been hampered by a poorly performing economy, outdated laws, the dominance of oligarchs and the lack of 'political will' of the political elite to tackle endemic corruption. More precise, the oligarchy stands in the way of any reform that may harm their interests. However, in this country, one rather uses the plural term oligarchs. There is only one oligarch of any importance and influence left: Mr Vlad Plahotniuc. His rival oligarchs are either disgraced or in jail or both. He is the puppet master for the entire country - nothing is decided or done without he says so (Calus, 2016b; Rahman, 2017: 6).

There is institutional weakness everywhere in Moldova. In particular the judiciary is weak and corrupt. The judiciary can act corruptively and engage in embezzlement and money laundering and again there are few convictions. Judges with low rankings can still be promoted to senior positions just because they are acceptable to Plahotniuc. Outspoken personalities in the judiciary are at risk of being harassed by allegations of wrong 
doing and the initiation of criminal investigations. After having caused professional and personal damage, these investigations usually come to an unexplained halt.

The banking sector is weak and prone to be victimized or undermined by internal corruption. The Laundromat case is a telling example. A billion dollars can disappear from the banks and hardly anyone is held accountable. Serious asset recovery has thus far not been undertaken. Who cares?

There are institutional 'guardians' against corruption. But the NAC and the Anti-corruption Prosecution office handled thus far mainly 'small fry'. The National Integrity Authority still demonstrates embarrassing delays. These institutions appear to be weak and less than transparent. It is very difficult to find any reports about their activities and any sort of accountability. Critics from civil society are of the opinion that the 'guardian' institutions are kept deliberately weak by appointing mediocracies in the leading ranks, especially in the system of justice and law enforcement.

The EU had made the transfer of final tranches of its aid funds dependent on real progress in judicial reform. Apart from such pressure, the EU should do more concerning training and expertise on the ground in Moldova to assist civil society involved in the fight against corruption.

Meanwhile, the reality on the ground is that nothing will happen against the interests of Plahotniuc and his clan, despite his unpopularity: in opinion polls $95 \%$ of interviewees say they distrust him (Całus, 2016b). If there is any chance of removing this obstacle, it will come from civil society that has to be strengthened.

\section{References}

BTI Moldova Report, BTI 2018 Country Report - Moldova., Gutersloh: Bertelsmann \& Stiftung, 2018.

Butkovic, H. and V. Samardzija, The fight against corruption in Moldova: What can be learned from Croatian Experiences, The Development of Democracy Conference, Zagreb 28-29 April, 2015.

Całus, K., The unfinished state. 25 years of independent Moldova. OSV Studies, 2016a. 
Całus, K., Moldova: from oligarchic pluralism to Plahotniuc's hegemony. Centre for Eastern Studies. No 208, 2016 b.

Carasciuc, L., Corruption and Quality of Governance. 2001. Available on http://www.transparencyinternational.md. Accessed on September $10^{\text {th }}, 2017$.

Chalidze, V., Criminal Russia, P.S. Falla, 1977.

Centre for Combating Economic Crime and Corruption. No date. Available at http://www.cccec.md/the-moldovan-banking-scandal/.

Clark, J. and A. Wildavsky, Why Communism Collapses: The moral and material failures of command economies are intertwined, Journal of Public Policy, 1990, Vol. 10 (4), 361-390.

Council of Europe, Report on the Corruption Risk Assessment within the Public Prosecution Service of Moldova, 2016. Available on http;//coe.int. Accessed 12 May 2018.

Cozonac, C., L. Stefan, S. Parvu and M. Podumlijak, Conflicts of Interest and Incompatibilities in Eastern Europe, Romania, Croatia, Moldova. 2012.

http://expertforum.ro/wp-content/uploads/2013/03/Conflicts-of-Interest and incompatibilities in Eastern Europe (Accessed 1 March 2018).

DKP Consulting, Moldova Anti-Corruption Assessment Final Report, USAID, 2006.

Duyne, P.C. van, Will Caligula go transparent? Corruption in Acts \& Attitude, Forum on Crime \& Society, 2001, Vol.1(2), 73-98.

European Commission, Report on Implementation by the Republic of Moldova of the Action Plan on Visa Liberalisation, 2012, available on http://ec.europa.eu/dgs/home-affairs/ Accessed on 15 March 2018.

Emerson M., N. Hriptievschi, O. Kalitenko,T. Kovziridze, E. Pochnitchi, Anti-corruption policies in Georgia, Moldova and Ukraine. 2017. www.3dcftas.eu/.

Feldbrugge, F.J.M., Government and Shadow Economy in the Soviet Union, Soviet Studies, 1984, 36(4), 528-543.

Freedom House, Moldova: A country in transit, Freedom House, 2018.

Gamurair, L. and C. Ghinea, It has only just begun: EU and anti-corruption institutions in Moldova, EPC Policy Brief 1 August 2014. Available on http://www.epc.eu/documents/uploads/pub 4683, Accessed on April $20^{\text {th }}, 2018$. 
Gribincea, V., Moldova: Investigating high level corruption - progress or illusion?, Soros Foundation: Moldova, 2017.

Gribincea, V., Analysis of the strategy for the recovery of funds defrauded from the banking system of the Republic of Moldova, Discussion Paper, 2018.

Hriptievschi, N., Independence \& accountability of Moldova's judiciary under threat. Legal Resource Center, Moldova, 2017.

Institute for Public Policies, Public Opinion Barometer, October, 2016

Jowitt, K., Soviet neo-traditionalism: The political Corruption of a Leninist Regime, Soviet Studies, 1983, 35(3), 275-297.

Kaufman, D., Corruption: The Facts, Foreign Policy, 1997 (107), 114-131.

Konończuk, W., D. Cenușa and K. Kakachia,. Oligarchs in Ukraine, Moldova and Georgia as key obstacles to reforms. 2017. www.3dcftas.eu/.

Kurat, A.N. and J.S. Bromley, The retreat of the Turks, 1683-1730. In M.A. Cook (ed.), A history of the Ottoman empire to 1730. Cambridge University Press, 1976.

Los Angeles Times, Soviets Uncover massive Corruption: Billions Lost in Uzbekistan Case Involving Brezhnev Kin, 1988. Available on: http://articles.latimes.com/1988-01-24/news/mn-38144_1_soviet-union. Accessed on June 3rd, 2018.

Markovska, A and A. Isaeva, Public Sector Corruption: Lessons to be learned from the Ukranian Experience, Crime Prevention \& Community Safety, 2007, Vol.9 (2), 118-129

McDevit, J., The state of corruption in Armenia, Azerbaijan, Moldova and Ukraine. 2015, EU.

NAC, Progress Report of the National Anti-Corruption Centre 2014-2015. 2016.

Novak, R., Corruption and Transition Economies, Paper presented to the $9^{\text {th }}$ OSCE Economic Forum, Bucharest, 27-28 March, 2001.

Prohnitchi, E., A fight against corruption in Moldova: what's wrong and what can be done?, Soros Foundation, Moldova, 2018.

Reuters,https://www.reuters.com/article/moldova-banking-platon/moldovan-businessman-jailed-for-role-in-1-billion-bank-fraudidUSL8N1HS3T0.

Simis, K., The machinery of corruption in the Soviet Union. Survey, 1977, Vol.23(4), 35-55. 
Sobjak, A., Anti-corruption in Moldova \& Ukraine. The Polish Institute of International Affairs, 2015. Available on http://www.pism.pl. Accessed on April $20^{\text {th }}, 2018$.

Soloviev, V., Moldova: the failing champion of European integration. Legatum Institute, 2014.

Stefan, L., N. Hriptievschi and V. Gribincea, Position paper: the anti-corruption prosecution office should investigate only high-level corruption. Legal Resources Centre from Moldova (LRCM) and Expert Forum from Romania (EFOR), 2018.

Stefes, C., New faces in post-soviet politics: does it really matter? Paper presented at Central Eurasian Studies Annual Conference, Cambridge, Massachusetts, 2003.

Svensson, J., Eight Questions about Corruption, Journal of Economic Perspectives, 2005, 19(3), 19-42.

Transparency International, Adept, LRCM, Legal Resources Centre from Moldova and DIS, State capture: the case of Moldova, Chisinau, 2017

Transparency International, CMI, Moldova: an overview of corruption and anti-corruption with a focus on the health care and procurement sectors. Anti-corruption Resource Centre, www.U4. no.

Transparency International, Exporting Corruption, Progress Report 2018: assessing enforcement of the OECD Anti-Bribery Convention, Transparency International, 2018.

UNDP, United Nations Development Programme Moldova. Strengthening Prevention and Analysis Functions of the National Anti-Corruption Centre (NAC), 2018. Available on www.undpmoldova.md Accessed on 20 April 2018.

UNDP, Assessment Report of corruption risks in public procurement in the Republic of Moldova, 2016. Available on http;//www.undpmoldova.md Accessed on 20 March 2018.

Vaksberg, A., Soviet Mafia, St. Martin's Press, 1991.

www.europalibera.org/a/27209223.html Accessed on 8 June 2018.

www.reuters.com/moldova-banking?moldovan businessmanjailed for role in $£ 1$ billion bank fraud, Accessed on 26 August 2018.

Zeppelin Investigations, Moldova: LAUNDROMAT, June, 2018. 